\title{
COMMENTARY
}

\section{Sequential C-reactive protein measurements in patients with serious infections: does it help?}

\author{
Suzana Margareth Lobo* \\ See related research by Coelho et al., http://ccforum.com/content/16/2/R53
}

\begin{abstract}
C-reactive protein (CRP) is a marker of inflammation traditionally used as a complementary tool to support the clinical diagnosis and as a marker of severity of disease. CRP is an acute-phase protein synthesized by the liver after stimulus by cytokines and its serum levels increase markedly within hours after the onset of infection, inflammation or tissue injury. Dynamic serial measurement of CRP has been widely used to help therapeutic decision-making. Decreasing plasma concentrations of this biomarker have been used as an indicator for resolution of infection or sepsis.
\end{abstract}

In the previous issue of Critical Care, Coelho and colleagues continued their longstanding work on Creactive protein (CRP) kinetics by evaluating the patterns of evolution of CRP in patients with severe communityacquired pneumonia (CAP) [1]. A time-dependent analysis was performed and CRP ratios were calculated daily in relation to the CRP concentration on day 0 , considered equal to 1 . They showed that survivors of CAP had a continuous decrease of the CRP ratio during the first week of antibiotic therapy. On the contrary, the CRP ratio remained elevated in nonsurvivors. A value above 0.5 on day 5 was associated with a fivefold increase in the risk of death in the ICU. These data suggest that persistently elevated CRP values are indicative of poor response to antibiotic therapy in patients with CAP.

Serious infections and sepsis demand prompt and appropriate antimicrobial therapy. Many studies have shown the usefulness of serial measurements of CRP as a tool in the follow-up of different conditions such as CAP [2], ventilator-associated pneumonia [3-5], bloodstream

*Correspondence: suzana-lobo@uol.com.br

Serviço de Terapia Intensiva, Faculdade de Medicina de São José do Rio Preto, Medical School - Hospital de Base, Av Faria Lima 5544, São Jose do Rio Preto, São Paulo CEP 15090-000, Brazil infection [6] and sepsis [7,8]. Distinct patterns of CRP kinetics were related to differences in outcomes and/or appropriateness of antibiotic therapy.

Ineffective empirical antimicrobial therapy or poor outcome was associated with increases in CRP concentrations in the first 48 to 72 hours in patients with bloodstream infection or sepsis [6-8], or with decreases to ratios $<0.4$ on the third day in patients with CAP [2] or $<0.6$ to 0.8 on the fourth day in patients with ventilatorassociated pneumonia [3-5].

The kinetics of CRP may be modified by age, genetic variability in the CRP gene, comorbidities, underlying conditions or therapeutic interventions other than antibiotics.

The use of CRP or other biomarkers is particularly important in older patients, who may have infection without fever, leucocytosis or other classical signs of infection. In older patients with very high CRP levels, infection was diagnosed in $75 \%$ of those with serum concentrations $>5.0 \mathrm{mg} / \mathrm{dl}$ and in $94 \%$ of those with concentrations $>10.0 \mathrm{mg} / \mathrm{dl}$ [9]. Minor increases in CRP concentrations may, however, represent subclinical illnesses such as cardiovascular diseases, cirrhosis, graft versus host disease, and systemic lupus erythematosus [10-12]. More elevated baseline plasma levels are associated with cancer [13]. In these conditions the persistence of high levels has suggested a complicated course, and a second increase is highly suggestive of an infectious complication. In septic critically ill cancer patients, CRP concentrations are more elevated in those with neutropenia [14].

The incidence of deep venous thrombosis in a group of high-risk ICU patients receiving deep venous thrombosis prophylaxis is about $12 \%$ [15]. CRP also increases in patients with deep venous thrombosis. The acute-phase response is induced by the initial formation of thrombus, and a delayed presentation of deep venous thrombosis would allow time for CRP to return to normal levels [16].

Transfusion of blood components is associated with an inflammatory response. Approximately $70 \%$ of patients with an ICU length of stay longer than 1 week receive a blood transfusion [17]. A delay in the decline of or no 
decline in CRP serum levels during the morning following transfusion must therefore be expected [18].

Conversely, some circumstances are expected to lower CRP levels. Glucocorticoids are the most important physiologic inhibitors of inflammation. Patients with acute respiratory distress syndrome treated with methylpredinisolone showed a significant reduction in CRP levels in comparison with those not receiving the drug [19]. CRP is more a marker of severe liver dysfunction than infection in patients with acute hepatic failure. Severe hepatic failure should be ruled out in patients with a high suspicion of infection and an abnormally low CRP concentration or with a marked CRP decline despite persistent septic shock [20].

Hence, failure of CRP levels to fall after 5 days should address additional investigation for inadequate antibiotic therapy, unrevealing resistant infection or localized pus, new infection or serious noninfectious pathology such as thrombosis or cancer. The usefulness of CRP as a surrogate of response to therapy has been widely studied. Use of CRP to guide the duration of antibiotic therapy and the potential of the combination of several biomarkers reflecting different pathophysiological pathways in improving the management of infections remain to be investigated.

\section{Abbreviations}

CAP, community-acquired pneumonia; CRP, C-reactive protein

\section{Competing interests}

The author declares that she has no competing interests.

Published: 18 June 2012

\section{References}

1. Coelho LM, Salluh JL, Soares M, Bozza F, Verdeal JCR, Castro-Faria-Neto HC, Lapa e Silva JR, Bozza PT, Póvoa P: Patterns of C-reactive protein RATIO response in severe community-acquired pneumonia: a cohort study. Crit Care 2012, 16:R53.

2. Bruns AH, Oosterheert JJ, Hak E, Hoepelman Al: Usefulness of consecutive C-reactive protein measurements in follow-up of severe communityacquired pneumonia. Eur Respir J 2008, 32:726-732.

3. Póvoa P, Coelho L, Almeida E, Fernandes A, Mealha R, Moreira P, Sabino H: C-reactive protein as a marker of ventilator-associated pneumonia resolution: a pilot study. Eur Respir J 2005, 25:804-808.

4. Lisboa T, Seligman R, Diaz E, Rodriguez A, Teixeira PJ, Rello J: C-reactive protein correlates with bacterial load and appropriate antibiotic therapy in suspected ventilator-associated pneumonia. Crit Care Med 2008, 36:166-171
5. Moreno MS, Nietmann H, Matias CM, Lobo SM: C-reactive protein: a tool in the follow-up of nosocomial pneumonia. J Infect 2010, 61:205-211.

6. Povoa P, Coelho L, Almeida E, Fernandes A, Mealha R, Moreira P, Sabino H: Pilot study evaluating C-reactive protein levels in the assessment of response to treatment of severe bloodstream infection. Clin Infect Dis 2005, 40:1855-1857.

7. Schmit $X$, Vincent $\mathrm{J}$ : The time course of blood C-reactive protein concentrations in relation to the response to initial antimicrobial therapy in patients with sepsis. Infection 2008, 36:213-219.

8. Póvoa P, Teixeira-Pinto AM, Carneiro AH; Portuguese Community-Acquired Sepsis Study Group SACiUCl: C-reactive protein, an early marker of community-acquired sepsis resolution: a multi-center prospective observational study. Crit Care 2011, 15:R169.

9. Cox ML, Rudd AG, Gallimore R, Hodkimon TM, Pepys MB: Real-time measurement of serum C-reactive protein in the management of infection in the elderly. Age Ageing 1986, 15:257-266.

10. Ridker PM, Hennekens $\mathrm{CH}$, Buring JE Rifai N: C-reactive protein and other markers of inflammation in the prediction of cardiovascular disease in women. NEngl J Med 2000, 342:836-843.

11. Cervoni JP, Thévenot T, Weil D, Muel E, Barbot O, Sheppard F, Monnet E, Di Martino V: C-reactive protein predicts short-term mortality in patients with cirrhosis. J Hepatol 2012, 56:1299-1304.]

12. Kushner I: C-reactive protein in rheumatology. Arthritis Rheum 1991, 34:1065-1068

13. Allin $\mathrm{KH}$, Bojesen SE, Nordestgaard BG: Baseline C-reactive protein is associated with incident cancer and survival in patients with cancer. $J$ Clin Oncol 2009, 27:2217-2224.

14. Póvoa P, Souza-Dantas VC, Soares M, Salluh JF: C-reactive protein in critically ill cancer patients with sepsis: influence of neutropenia. Crit Care 2011, 15:R129.

15. Marik PE, Andrews $L$, Maini $B$ : The incidence of deep venous thrombosis in ICU patients. Chest 1997, 111:661-664.

16. Thomas EA, Cobby MJ, Rhys D, Jeans WD, Whicher JT: Liquid crystal thermography and $C$ reactive protein in the detection of deep venous thrombosis. BMJ 1989, 299:951-952.

17. Vincent Jl, Baron JF, Reinhart K, Gattinoni L, Thijs L, Webb A, Meier-Hellmann A, Nollet G, Peres-Bota D; ABC Investigators: Anemia and blood transfusion in critically ill patients. JAMA 2002, 288:1499-1507.

18. Cholette JM, Henrichs KF, Alfieris GM, Powers KS, Phipps R, Spinelli SL, Swartz M, Gensini F, Daugherty LE, Nazarian E, Rubenstein JS, Sweeney D, Eaton M, Lerner NB, Blumberg N: Washing red blood cells and platelets transfused in cardiac surgery reduces postoperative inflammation and number of transfusions: results of a prospective, randomized, controlled clinical trial. Pediatr Crit Care Med 2011, 13:290-299.

19. Meduri GU, Golden E, Freire AX, Taylor E, Zaman M, Carson SJ, Gibson M, Umberger R: Methylprednisolone infusion in early severe ARDS: results of a randomized controlled trial. Chest 2007, 131:954-963.

20. Silvestre JP, Coelho LM, Povoa PM: Impact of fulminant hepatic failure in C-reactive protein? Crit Care 2010, 25:657.

doi:10.1186/cc11347

Cite this article as: Lobo SM: Sequential C-reactive protein measurements in patients with serious infections: does it help? Critical Care 2012, 16:130. 